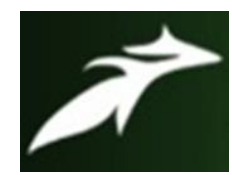

LAVUDYA ARUN KUMAR et al, International Journal of Advances in Agricultural Science and Technology,

Vol.8 Issue.8, August-2021, pg. 121-133

\title{
To Ascertain the Level of Knowledge of Beneficiaries Regarding Integrated Tribal Development Agency (ITDA) Providing Farm Services Adilabad District of Telangana
}

\author{
LAVUDYA ARUN KUMAR \\ I.D NO 19MSAEC081 \\ Msc. Ag.(Agricultural Extension \& Communication), SHUATS (Prayagraj) \\ Prof. Dr. Syed H. Mazhar \\ Associate Professor, Department of Agriculture Extension and Communication, SHUATS (Prayagraj) \\ Prof. Dr. Jahanara \\ Head, Department of Agriculture Extension and Communication), SHAUTS (Prayagraj) \\ DOI: 10.47856/ijaast.2021.v08i8.014
}

\begin{abstract}
The present study would be carried out in the tribal dominant area of Integrated Tribal Development Agency (ITDA) Utnoor of Erstwhile Adilabad district in Telangana State. After reorganization of districts in Telangana State, ITDA, Utnoor spread over four districts namely Adilabad, Asifabad, Nirmal, and Mancherial. As per 2011 census in Telangana State total tribal population constitute 9.08\% The population of Erstwhile Adilabad district is 27, 41,238 and among them 4, 95,794 people were tribes. There are 32 tribal communities in Telangana State where eight tribes dwelling in the Erstwhile Adilabad district, such as Gond-2,55,403, Lambada 1,43,554, Kolam/Mane- 52,772, Koya-26534, Pardhan-16,667, Andh-9922, Thoti-8998. Among them kolam and Thoti are Primitive Tribal Group (PTG)With the advent of ITDAs (Integrated Tribal Developmental Agencies), developmental efforts of various departments (Agriculture, Horticulture, Veterinary and Rural works departments) have been channelled through a single window system. Agriculture being the main thrust area, ITDAs is focusing on improving the productivity of the crops by provisioning inputs such as seeds of improved varieties, and chemicals to make the farmers economically better off. 120 respondents from utnoor mandal were randomly selected and data were collected and analysed by using appropriate statistical tool. (48.33\%) of the respondents have Medium level of the knowledge about ITDA Farm services. Variables like age, caste, occupation, annual income, extension contacts and risk orientation has no significance relationship with the knowledge on ITDA Farm , while variables like gender, land holding, education, mass media and extension contacts, innovativeness, risk orientation have positive correlation with the knowledge on ITDA Farm services.
\end{abstract}

\section{INTRODUCTION}

Tribal people are children of nature and their lifestyle is conditioned by the ecosystem. They are clearly different from the mainstream and dominant society. There are approximately 200 million tribal people in the entire globe accounting for about $4 \%$ of the global population. India is the home for a number of tribes i.e. groups of indigenous people who are still untouched by the lifestyles of world. 


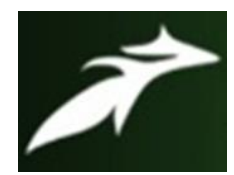

LAVUDYA ARUN KUMAR et al, International Journal of Advances in Agricultural Science and Technology, Vol.8 Issue.8, August-2021, pg. 121-133

ISSN: 2348-1358

Impact Factor: 6.057

NAAS Rating: 3.77

The word "tribe" means a group of families bound together by kinship, usually descending from common mythical or legendary ancestor living in a contiguous region, speaking common language and having common historical past. India has one of the largest concentrations of tribal population in the world. As per the 2011 census, the scheduled tribe population in India is 8.43 crore, constituting 8.6 percent of the total population.

Tribal communities live in about 15 per cent of the country's areas and government has identified more than 697 tribal communities in various ecological and geoclimatic conditions ranging from plains, forests, hills and inaccessible areas. Most of these communities are found inhabiting in the forests. The population density in tribal areas is 125 persons per sq.km as against194 in the plain areas. In this land of cultural diversity, along with the general population, people belonging to underprivileged sections of society including schedule castes and tribes have contributed a lot for our national heritage by their unique style of performing certain jobs and festivals. Every community has its own way to meet its basic needs for the existence of its members failing which they are threatened with extinction. Nature here comes forward and joins hands with tribal's to fulfill their needs fashioned of course in their way depending on their customs, traditions, demographic structures etc.. (Vidyarthi and Rai,1976). Besides providing food crops, a number of forest produce are harvested seasonally by the tribal's to eke out hand to mouth living. Over millennia, these people learnt to live in harmony with the nature in a sustainable manner and stand as custodians of the valuable natural resource base "the forests". The socio-economic structure in tribal communities is markedly different from that of the non-tribal. They have a very simple technology which fits well within their ecological surroundings and conservative outlook. Moreover, their economy can be termed as subsistence type (Vidyarthi and Rai, 1985). The first and foremost characteristic of the tribal community is the close relationship between their economic life and the natural environment or habitat which is, in general, the forest. Accordingly, Integrated Tribal Development Agencies (ITDAs) were established with an object of termination of exploitation in all forms, speeding up of the process of social and economic development building up inner strength of people and improving the organizational capabilities. Accordingly, "Integrated Tribal Development Agency was registered under societies Act XXI of 1860 with an objective to identify the problems of tribals in the agency area and to investigate into problems with a view to formulate firm measures for the development of the area and improving the economic \& educational standards and maintain the cultural heritage of the tribes. The Scheduled Tribe Groups who were identified as more backward communities among the Tribal population groups have been categorized as Primitive Tribal Groups (PTGs) by the central government in 1975.So far, seventy-five tribal communities have been identified as PTG groups in different States of India. These hunting, food gathering, and some agricultural communities, which have been identified as more backward communities among the tribal population groups need special programmes for their sustainable development. 


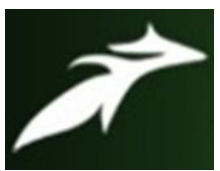

LAVUDYA ARUN KUMAR et al, International Journal of Advances in Agricultural Science and Technology, Vol.8 Issue.8, August-2021, pg. 121-133

ISSN: 2348-1358

Impact Factor: 6.057

NAAS Rating: 3.77

\section{SPECIFIC OBJECTIVE OF THE STUDY:}

1. To ascertain the level of knowledge of beneficiaries regarding Integrated Tribal Development Agency Farm services.

\section{REVIEW OF LITERATURE}

Kira and Mehta (2009) revealed that maximum number of the contact tribal farmers (51.67\%) had medium knowledge level of recommended rice production technology followed by 33.33 per cent and 15.00per cent of the farmers had low and high knowledge level of recommended rice technology, respectively. Whereas, the nearly half $(49.58 \%)$ of non-contact tribal farmers had medium knowledge level of rice production technology followed by the rest with low (42.08\%) and high (8.34\%) knowledge level of rice production technology

Valeria et al.(2010) reported that tribes have rich knowledge about the indigenous practices especially in soil management, seed protection and post harvest aspect on paddy. 23.00 per cent respondents use Dhenki for dehusking paddy, 77.00 per cent respondents used Parsa leaf in rice field to control insects

Bankey et al. (2012) reported that 78.00 per cent of the tribal women had low knowledge in modern farming followed by 18.67 per cent with medium knowledge and 3.33 per cent with high level of knowledge

Swathi (2012) reported that less than half (40.83\%) of the tribal respondents had high knowledge on Agro biodiversity followed by those with medium (31.67\%) and low $(27.50 \%)$ knowledge

Kapur et al.(2013) in their study on knowledge and attitude of tribal farmers of valsad district towards soil testing reported that majority of adopters believed that soil testing is 


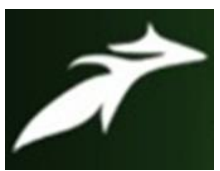

LAVUDYA ARUN KUMAR et al, International Journal of Advances in Agricultural Science and Technology, Vol.8 Issue.8, August-2021, pg. 121-133

ISSN: 2348-1358

Impact Factor: 6.057

NAAS Rating: 3.77

useful, reduce the use of chemical fertilizers and it is necessary for sustainable soil health and productivity.

Kavitha et al. (2014) reported that majority (75.33\%) of the respondents had medium level of knowledge followed by the remaining withhigh knowledge level (16.00\%) and low knowledge level $(8.67 \%)$ towards goat farming

Nagendrababu (2015) reported that more than half $(55.00 \%)$ of the farmers of adopted village had medium level knowledge followed by those with high $(37.00 \%)$ and low $(8.00 \%)$ level of knowledge. Whereas, in case of non-adopted village, less than half $(47.00 \%)$ of the respondents had medium level of knowledge followed by those with high $(35.00 \%)$ and low (18.00\%) level of knowledge about the crops like rice, maize, black gram and green gram

Archana (2016) reported that more than half (57.50\%) of the MGNREGA beneficiaries had medium knowledge followed by those with high (23.33\%) and low(19.17\%) knowledge

Swathi (2016) reported that more than half $(56.25 \%)$ of the tribal farmers had medium knowledge followed by those with low $(29.17 \%)$ and high $(14.58 \%)$ knowledge towards their existing livelihood systems

Archana (2016) reported that more than half (57.50\%) of the MGNREGA beneficiaries had medium knowledge followed by those with high (23.33\%) and low (19.17\%) knowledge 


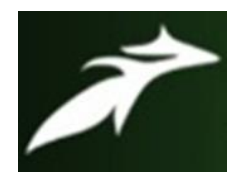

LAVUDYA ARUN KUMAR et al, International Journal of Advances in Agricultural Science and Technology, Vol.8 Issue.8, August-2021, pg. 121-133

ISSN: 2348-1358

Impact Factor: 6.057

NAAS Rating: 3.77

\section{RESEARCH METHODOLOGY}

\section{LOCALE OF THE STUDY:}

Adilabad district of Telangana is selected Purposively for the present studyAccording to the Census of India, the Adilabad district has a population of 27,41,238. Population of scheduled tribe were $18.1 \%$ of population of adilabad district of Telangana, with total of 495,794 (247,472 male) and (248,322 female). There are 32 tribal communities in Telangana State where eight tribes dwelling in the Erstwhile Adilabad district such as Gond-2,55,403, Lambada 1,43,554, Kolam/Mane- 52,772,Koya-26534,Pardhan- 16,667, Andh-9922, Thoti8998. Among them Kolam and Thoti are Primitive Tribal Group (PTG) The Geo Coordinates of the district are Latitude: $19^{\circ} 40^{\prime} 12.00^{\prime \prime} \mathrm{N}$, Longitude: $78^{\circ} 31^{\prime} 48.00^{\prime \prime}$ E. The Adilabad district is located in the Telangana state of India. It is bordered to the north by the Yavatmal district, to the northeast by the Chandrapur district, to the east by the Asifabad district, to the southeast by the Mancherial district, to the south by the Nirmal district, and to the west by ere is 1 Municipality in the District. The District is conveniently formed into 2 revenue divisions 1) Adilabad 2) Utnoor. The Geo Coordinates of the district are Latitude: $19^{\circ} 40^{\prime} 12.00^{\prime \prime} \mathrm{N}$ Longitude: $78^{\circ} 31^{\prime} 48.00^{\prime \prime}$ E. The Adilabad district is located in the Telangana state of India. The district has population of 7,08,972 which accounts for $3.13 \%$ of the total population of the State. The District Comprises of 18 Mandals and 508 villages. There is 1 Municipality in the District. The District is conveniently formed into 2 revenue divisions 1) Adilabad 2) Utnoor. The rainfall in the district, in general increases from the south-west towards the north east. About $85 \%$ of annual rainfall is received during the south-west monsoon season. July being the peak rainy month. The variation in the Annual rainfall from year is not large. The normal Annual rainfall of the district is $1044.5 \mathrm{~mm}$ Red and black soil are both found in Adilabad district though black soil predominates accounting for almost $72 \%$ of the soil in the district. The mineral resources are mainly limestone and manganese ore .major crops cultivated in selected area is rice, cotton. The state of Telangana was chosen for the study purposively as the ITDA, utnoor, Ailabad district located here and researcher belonged to this state and well acquainted with the local language(Telugu, Lambad, gondi, )which would 


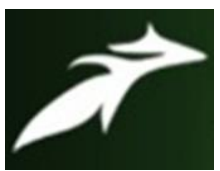

LAVUDYA ARUN KUMAR et al, International Journal of Advances in Agricultural Science and Technology, Vol.8 Issue.8, August-2021, pg. 121-133

ISSN: 2348-1358

Impact Factor: 6.057

NAAS Rating: 3.77

help in building up good rapport and also facilitates in depth study through personal observation and intense probing using well designed schedule.

\section{Operationalization and measurement of variables}

\section{Variables and their measurements}

The appropriate variables for the present study were prepared based on the objectives of the study, review of literature, discussion with experts and also the observations made by the researchers.

\section{Dependent Variables:}

\section{Knowledge}

Knowledge were operationally defined in this study as the degree of positive or negative feeling, beliefs, viewpoints and judgments expressed by the tribal farmers of ITDA towards its Farm services of ITDA. Here, the agricultural activities means Farming activities implemented under National Food security Mission (NFSM) and Rashtriya krishi Vikas Yojana (RKVY) et., in ITDA area. The knowledge of the tribal farmers of ITDA towards the Farm services of ITDA were measured by the scale developed to know the knowledge especially constructed to meet the objectives. it was measured in terms of scores and responses were recorded on three-points continuum in which the weightage of 3 Agree, 2 Undecided and 1 for Disagree were assigned for ITDA farming activities. Total score obtained by the respondents from all Farming Activities was the knowledge score of individual respondent. On the basis of minimum and maximum possible score, the categories were developed as:

\begin{tabular}{|l|c|}
\hline Categories score & Score \\
\hline Agree & 3 \\
\hline Undecided & 2 \\
\hline Dis agree & 1 \\
\hline
\end{tabular}




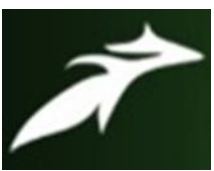

LAVUDYA ARUN KUMAR et al, International Journal of Advances in Agricultural Science and Technology, Vol.8 Issue.8, August-2021, pg. 121-133

\begin{tabular}{|l|l|}
\hline CATEGORY & SCORE \\
\hline Low & $(<$ Mean - SD $)$ \\
\hline Medium & (in between Mean \pm SD $)$ \\
\hline High & $(>$ Mean + SD $)$ \\
\hline
\end{tabular}

\section{RESULT AND DISCUSSION}

To ascertain the level of knowledge of beneficiaries regarding ITDA farm services

\begin{tabular}{|l|l|l|l|}
\hline S.No & Category & Frequency & Percentage \\
\hline 1 & Low & 10 & 8.33 \\
\hline 2 & Medium & 58 & 48.33 \\
\hline 3 & High & 52 & 43.33 \\
\hline & Total & 120 & 100 \\
\hline
\end{tabular}

Distribution of respondents according to their level of knowledge Regarding ITDA farm

From above table 4.20 Majority (48.33\%) of the farmers had Medium knowledge towards the ITDA farm services followed by High $(43.33 \%)$ and rest $(8.33 \%)$ of the farmers had low level of knowledge towards ITDA Farm services. 


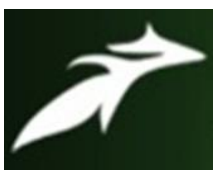

LAVUDYA ARUN KUMAR et al, International Journal of Advances in Agricultural Science and Technology, Vol.8 Issue.8, August-2021, pg. 121-133

\section{KNOWLEDGE REGARDING ITDA FARM SERVICES}

60

50

48.33

43.33

40

30

20

10

8.33

0

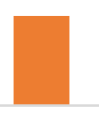

LOW

MEDIUM

$\mathrm{HIGH}$

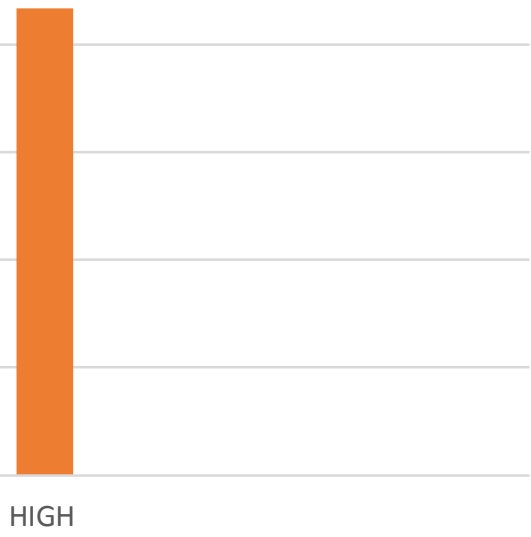

Distribution of farmers according to their level of knowledge about ITDA farm services.

To ascertain the level of knowledge of beneficiaries regarding ITDA farm services.

Please indicate your degree of Agree (A), Un decided (UD), Disagree (DA) Frequency (F), Percentage (P \%).]

$(\mathbf{n}=120)$

\begin{tabular}{|l|l|l|l|l|l|l|l|c|}
\hline SL. & \multicolumn{2}{|c|}{ STATEMENT } & \multicolumn{2}{c|}{ Agree } & \multicolumn{2}{c|}{ Un decided } & \multicolumn{2}{c|}{ Dis agree } \\
\cline { 3 - 8 } & & F & P (\%) & F & P (\%) & F & P (\%) \\
\hline 1. & $\begin{array}{l}\text { The variety of rice seed } \\
\text { supplied under ITDA is not } \\
\text { suitable to locality }\end{array}$ & - & - & 116 & 96.66 & 4 & 3.33 \\
\hline 2. & $\begin{array}{l}\text { Time of rice seed supplied } \\
\text { under ITDA is appropriate }\end{array}$ & 102 & 86.66 & 18 & 15 & - & - \\
\hline
\end{tabular}




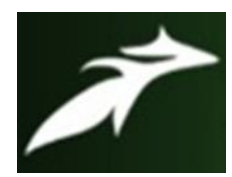

LAVUDYA ARUN KUMAR et al, International Journal of Advances in Agricultural Science and Technology, Vol.8 Issue.8, August-2021, pg. 121-133

ISSN: 2348-1358

Impact Factor: 6.057

NAAS Rating: $\mathbf{3 . 7 7}$

\begin{tabular}{|c|c|c|c|c|c|c|c|}
\hline 3. & $\begin{array}{l}\text { price of rice seed supplied } \\
\text { under ITDA is not } \\
\text { appropriate }\end{array}$ & 10 & 8.33 & 110 & 91.66 & - & - \\
\hline 4. & $\begin{array}{l}\text { Training provided on rice } \\
\text { crop cultivation under ITDA } \\
\text { is not timely }\end{array}$ & 26 & 21.66 & 90 & 75 & 4 & 3.33 \\
\hline 5. & $\begin{array}{l}\text { Field visit conducted by } \\
\text { ITDA officials to tribal } \\
\text { farmers fields of rice crop } \\
\text { were not adequate }\end{array}$ & 47 & 39.16 & 73 & 60.83 & - & - \\
\hline 6. & $\begin{array}{l}\text { Demonstration conducted in } \\
\text { rice crop under ITDA are } \\
\text { adequate }\end{array}$ & 102 & 85 & 14 & 11.66 & 4 & 3.33 \\
\hline \multicolumn{8}{|c|}{ B. cotton crop } \\
\hline 7. & $\begin{array}{l}\text { Quantity of cotton crop seed } \\
\text { supplied by ITDA is } \\
\text { adequate }\end{array}$ & 108 & 90 & 08 & 6.66 & 4 & 3.33 \\
\hline 8. & $\begin{array}{l}\text { Time of cotton crop seed } \\
\text { supplied by ITDA is not } \\
\text { appropriate }\end{array}$ & 15 & 12.5 & 105 & 87.5 & - & - \\
\hline 9. & $\begin{array}{l}\text { Price of cotton crop seed } \\
\text { supplied by ITDA is } \\
\text { reasonable }\end{array}$ & 111 & 92.5 & 09 & 7.5 & - & - \\
\hline
\end{tabular}




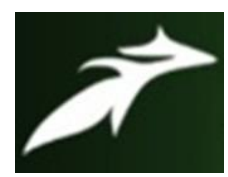

LAVUDYA ARUN KUMAR et al, International Journal of Advances in Agricultural Science and Technology, Vol.8 Issue.8, August-2021, pg. 121-133

ISSN: 2348-1358

Impact Factor: 6.057

NAAS Rating: $\mathbf{3 . 7 7}$

\begin{tabular}{|c|c|c|c|c|c|c|c|}
\hline 10. & $\begin{array}{l}\text { Training provided on cotton } \\
\text { crops cultivation under } \\
\text { ITDA is not timely }\end{array}$ & 53 & 44.16 & 65 & 54.16 & 2 & 1.66 \\
\hline 11. & $\begin{array}{l}\text { Field visits conducted by } \\
\text { ITDA officials to tribal } \\
\text { farmers fields of cotton } \\
\text { crops were timely }\end{array}$ & 106 & 88.33 & 11 & 9.16 & 03 & 2.5 \\
\hline 12. & $\begin{array}{l}\text { Demonstrations conducted } \\
\text { on cotton crops under ITDA } \\
\text { are timely }\end{array}$ & 63 & 52.5 & 4 & 3.33 & 53 & 44.16 \\
\hline 13. & $\begin{array}{l}\text { Demonstration conducted } \\
\text { on cotton crops under ITDA } \\
\text { are timely }\end{array}$ & 17 & 14.16 & 103 & 85.83 & - & - \\
\hline \multicolumn{8}{|c|}{ C. Farm Mechanization } \\
\hline 14. & $\begin{array}{l}\text { Price of oil engines supplied } \\
\text { by ITDA is high }\end{array}$ & - & - & 116 & 96.66 & 4 & 3.33 \\
\hline 15. & $\begin{array}{l}\text { Price of mini tractors } \\
\text { supplied by ITDA is high }\end{array}$ & 12 & 10 & 108 & 90 & - & - \\
\hline 16. & $\begin{array}{l}\text { Price of sprayers supplied } \\
\text { by ITDA is high }\end{array}$ & 14 & 11.66 & 106 & 88.33 & - & - \\
\hline 17. & $\begin{array}{l}\text { The subsidy amount given } \\
\text { for sprayers by ITDA. }\end{array}$ & 66 & 55 & 2 & 1.66 & 52 & \\
\hline 18. & $\begin{array}{l}\text { The price of Agri - } \\
\text { Borwells supplied by ITDA }\end{array}$ & 18 & 15 & 102 & 85 & - & - \\
\hline
\end{tabular}




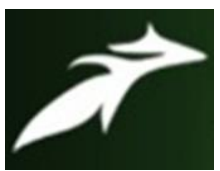

LAVUDYA ARUN KUMAR et al, International Journal of Advances in Agricultural Science and Technology, Vol.8 Issue.8, August-2021, pg. 121-133

ISSN: $2348-1358$

Impact Factor: 6.057

NAAS Rating: 3.77

\begin{tabular}{|c|c|c|c|c|c|c|c|}
\hline & is high & & & & & & \\
\hline 19. & $\begin{array}{l}\text { The subsidy amount given } \\
\text { for agri - borwells by ITDA } \\
\text { is adequate }\end{array}$ & 90 & 75 & - & - & 30 & 25 \\
\hline 20. & $\begin{array}{l}\text { The subsidy amount given } \\
\text { for sprayers by ITDA is } \\
\text { adequate }\end{array}$ & 80 & 66.66 & - & - & 40 & 33.33 \\
\hline
\end{tabular}

An attempt was made to find out the response of respondents towards a set of level of knowledge beneficiaries regarding ITDA farm services.

Relationship of Independent Variables with knowledge on ITDA Farm services

\begin{tabular}{|l|l|l|}
\hline S.No & \multicolumn{1}{|c|}{ Variables } & \multicolumn{1}{c|}{ 'r' value } \\
\hline 1. & Age & $0.385^{* *}$ \\
\hline 2. & Education & $-0.878^{* *}$ \\
\hline 3. & Annual Income & $-0.382^{* *}$ \\
\hline 4. & Extension contacts & $0.745^{* *}$ \\
\hline 5. & Mass Media Exposure & $0.874 * *$ \\
\hline 6. & Innovativeness & $0.608 * *$ \\
\hline 7. & Economic orientation & $0.462 * *$ \\
\hline 8. & Risk orientation & $0.429 * *$ \\
\hline 9. & Scientific orientation & $0.515^{* *}$ \\
\hline
\end{tabular}

** $0.01 \%$ level of Significant

$* 0.05 \%$ level of Significant.

NS - Non Significant.

The above table shows the relationship of independent variables with the knowledge of beneficiaries regarding ITDA Farm services. Variables like Age, Education, Annual income, Extension contacts, Mass media exposure, Innovativeness, Economic 


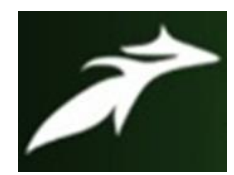

LAVUDYA ARUN KUMAR et al, International Journal of Advances in Agricultural Science and Technology, Vol.8 Issue.8, August-2021, pg. 121-133

ISSN: 2348-1358

Impact Factor: 6.057

NAAS Rating: 3.77

orientation, Risk orientation and Scientific orientation has positive and high significance relationship at $0.01 \%$ level of probability with the Knowledge of beneficiaries regarding ITDA farm services.

\section{CONCLUSION}

The Integrated Tribal development agency (ITDA) came in to existence on 1975 with headquarters at Adilabad. The purpose of establishment of ITDA is to cater the needs of the tribal community especially gonds, lambadas etc., where the predominant population living in across the project area by taking up of various livelihood activities through bank linkages as well community development in convergence with line departments support meant for the upliftment of the downtrodden tribal community. ITDA have been as additional institutions for delivery of public goods and services to scheduled tribes. These agencies function under overall control of the state govt. Tribal are confined to economic and social backwardness and it is one of the important problems in the country. Tribal in this country can be described as the poorest among the poor. Tribal living in forests and depending on forests for livelihood are being uprooted along with forests. On the one side, they are losing the basic support of life and on the other side they are not being brought into the mainstream of modern Indian development process. ( $48.33 \%$ ) of the respondents have Medium level of the knowledge about I.T.D.A Farm services like Rice crop, Cotton crop and Farm mechanization.43.33\% of the respondents have High level of the knowledge about I.T.D.A Farm services. The above table shows the relationship of independent variables with the level of knowledge on I.T.D.A Farm services. Variables like age, Education, annual income, extension contacts, mass media exposure, innovativeness, economic orientation, risk orientation and scientific orientation has positive and high significance relationship at 0.01 level of probability with the knowledge on ( I.T.D.A) Farm services. Most of the respondents were having medium level of knowledge about ITDA Farm services. 


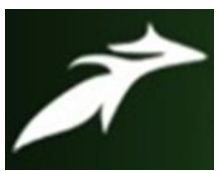

LAVUDYA ARUN KUMAR et al, International Journal of Advances in Agricultural Science and Technology, Vol.8 Issue.8, August-2021, pg. 121-133

ISSN: 2348-1358

Impact Factor: 6.057

NAAS Rating: 3.77

\section{REFERENCES}

[1]. Dhanasree, K., Vijaya bhinandana, B and Pradeep kumar, P.B. 2014.Socio Economic empowerment of tribal women in high altitude and Tribal Zone of Andhra Pradesh. International Journal of Innovative Research in Science, Engineering and Technology. 3 (2): 9360-9368

[2]. Nagendrababu, N. 2015.Impact of Village Adoption Programme (VAP) in Appikatla village of Guntur district. M.Sc.(Ag.) Thesis.Acharya N.G.RangaAgricultural University, Bapatla, India

[3]. Archana, K. 2016. A study on impact of Mahatma Gandhi National Rural Employment Guarantee Scheme in Srikakulam district of Andhra Pradesh. M.Sc.(Ag.)Thesis. ANGRAU, Guntur India.

[4]. Swathi, G. 2016. A study on livelihoods of tribal farmers in Andhra Pradesh. Ph.D. Thesis. Acharya N.G. Ranga Agricultural University, Lam, Guntur.

[5]. Ramya, H.R.2016. Livelihood analysis of tribal farmers in high altitude tribal zone of Karnataka State. MSc. (Ag.) Thesis.Acharya N.G. Ranga Agricultural University, Lam, Guntur.

[6]. Lal, B. Suresh. (2019), Tribal Development in India: Some Observations, Researchgate.

[7]. https://www.researchgate.net/publication/334680540_Tribal_Development_in_India_ Some Observations (28 December 2019) 